\title{
Gorontalo
}

Journal of Public Health

Volume 2 - No. 2 - Oktober 2019

P-ISSN: 2614-5057, E-ISSN: 2614-5065

\section{Pelaksanaan PSN 3M Plus untuk Pencegahan \\ Demam Berdarah Dengue \\ (Studi Kasus Masyarakat Desa Kamal)}

\section{Implementation of PSN 3 M Plus for Prevention Dengue Hemorrhagic Fever (Case Study of Kamal Village Community)}

\author{
Firdausi Ramadhani ${ }^{1 *}$, Ririh Yudhastuti ${ }^{2}$, Sri Widati ${ }^{3}$ \\ ${ }^{1}$ Fakultas Kesehatan Masyarakat, Universitas Gorontalo \\ Gorontalo, Indonesia \\ *email : firdausirmd@yahoo.com \\ ${ }^{2}$ Departement Kesehatan Lingkungan, Fakultas Kesehatan Masyarakat, \\ Universitas Airlangga, Surabaya, Indonesia \\ ${ }^{3}$ Departement Promosi Kesehatan dan Ilmu Perilaku, Fakultas Kesehatan Masyarakat, \\ Universitas Airlangga, Surabaya, Indonesia
}

\begin{abstract}
Based on data from Bangkalan District health profile in 2010, total DHF cases were 709 cases. In 2011 there was a decline in cases, namely 226 people and one person died. In 2012 there was a surge in 397 cases and six people were declared dead (Bangkalan District Health Profile 2010-2012). Bangkalan District Health Office has sought various programs to deal with dengue cases. This study aims to determine the knowledge and implementation of the Eradication of Mosquito Nests. Using qualitative methods with a case study approach. Data collection was carried out during the period of April-June 2017. The population is in part of the community living in Kamal Sub-district. Data was collected through interviews with housewives from Kamal Village, community leaders and Puskesmas officers. From the results of the study it was found that public knowledge about 3M Plus DHF and PSN was still low. Communities are more familiar with fogging and larvacide to combat dengue than the 3M Plus PSN program. The low implementation of 3M Plus $P S N$ and the lack of information on $3 M$ Plus DBD and PSN. As a recommendation, the relevant parties should immediately take strategic and technical steps in implementing the 3M Plus PSN as the main approach in DHF control. Facilitating partnerships between communities and the government and seeking community participation in tackling DHF through PSN mobilization activities. Expanding access to information about $3 M$ Plus DHF and PSN, not only in schools but also covering all levels of society.
\end{abstract}

Keywords; DHF, fogging, larvasida

\begin{abstract}
Abstrak
Berdasarkan data profil kesehatan Kabupaten Bangkalan tahun 2010 kasus DBD total penderita sebanyak 709 kasus. Pada tahun 2011 sempat mengalami penurunan kasus yaitu dengan jumlah 226 penderita dan satu orang dinyatakan meninggal. Pada tahun 2012 kembali mengalami lonjakan yaitu 397 kasus dan enam orang dinyatakan meninggal (Profil Kesehataan Kabupaten Bangkalan 2010-2012). Dinas Kesehatan Kabupaten Bangkalan sudah mengupayakan berbagai program untuk mengatasi kasus DBD. Penelitian ini bertujuan untuk
\end{abstract}


mengetahui pengetahuan dan pelaksanaan Pemberantasan Sarang Nyamuk. Menggunakan metode kualitatif dengan pendekatan studi kasus. Pengumpulan data dilakukan selama periode Bulan April-Juni 2017. Populasinya sebagian masyarakat yang tinggal di Kecamatan Kamal. Data dikumpulkan melalui wawancara dengan ibu rumah tangga Desa Kamal, tokoh masyarakat dan petugas Puskesmas. Dari hasil penelitian ditemukan bahwa pengetahuan masyarakat tentang DBD dan PSN 3M Plus masih rendah. Masyarakat lebih mengenal fogging dan larvasida untuk menanggulangi DBD daripada program PSN 3M Plus. Rendahnya pelaksanaan PSN 3M Plus dan minimnya informasi mengenai DBD dan PSN 3M Plus. Sebagai rekomendasi, sebaiknya pihak terkait segera mengambil langkah strategis dan teknis dalam pelaksanaan PSN 3M Plus sebagai pendekatan utama dalam pengendalian DBD. Memfasilitasi kemitraan antara masyarakat dan pemerintah serta mengupayakan partisipasi masyarakat dalam menanggulangi DBD melalui kegiatan penggerakan PSN. Memperluas akses informasi tentang DBD dan PSN 3M Plus, bukan hanya di sekolah namun juga mencakup seluruh lapisan masyarakat.

Kata kunci; DBD, fogging, larvasida

\section{PENDAHULUAN}

Organisasi Kesehatan Dunia (WHO) menyatakan Penyakit Demam Berdarah Dengue (DBD) masih merupakan salah satu masalah kesehatan di dunia. Jumlah penderita dan luas daerah penyebarannya semakin bertambah seiring dengan meningkatnya mobilitas dan kepadatan penduduk. Di Indonesia demam berdarah pertama kali ditemukan di kota Surabaya pada tahun 1968, sejumlah 58 orang terinfeksi dan 24 orang diantaranya meninggal dunia. Sejak saat itu, penyakit ini menyebar luas ke seluruh Indonesia (Departemen Kesehatan RI, 2010). Kejadian DBD di Indonesia dari Tahun 2012-2014 kasus DBD mengalami kenaikan pada tahun 2013. Pada tahun 2014 mengalami penurunan kasus penderita DBD, namun yang meninggal masih tergolong tinggi, yaitu lebih dari 100 orang (Kementerian Kesehatan RI, 2014). Berdasarkan Profil Kesehatan Provinsi Jawa Timur, kejadian DBD dari tahun 2012-2014, kejadian DBD di Jawa Timur mengalami peningkatan di tahun 2013 dan mengalami penurunan di tahun 2014, namun masih tinggi dibanding pada tahun 2012 (Profil Kesehatan Provinsi Jawa Timur, 2012-2014). Pada tahun 2015 Kabupaten Bangkalan merupakan salah satu dari lima kabupaten kategori KLB DBD di Propinsi Jawa Timur. Pada tahun 2010-2015 angka kejadian DBD di Kabupaten Bangkalan mengalami fluktatif. Sedangkan kasus DBD di Kecamatan Kamal ada tahun 2013 angka kejadian DBD sangat tinggi, walaupun mengalami penurunan di tahun 2014. Masih tingginya angka kejadian DBD di Kecamatan Kamal, membuktikan bahwa penyebaran virus penyebab DBD semakin mudah untuk menular. Berbagai upaya telah dilakukan dalam penanggulangan DBD, dan salah satunya adalah Program Pemberantasan Sarang Nyamuk (PSN).

Program PSN telah diintensifkan sejak tahun 1992. Pada tahun 2000 dikembangkan menjadi 3M Plus yaitu dengan cara menggunakan larvasida, memelihara ikan dan mencegah gigitan nyamuk. PSN ini ternyata tidak berdampak secara signifikan. Hal ini karena tidak semua masyarakat terlibat dalam pelaksanaan PSN (Krianto, 2009). PSN tidak mungkin dapat tuntas dilakukan bila anggota masyarakat sampai ke lingkungan terkecil, yaitu rumah tangga tidak melakukannya. Praktik PSN dikatakan berjalan dengan baik apabila seseorang telah melaksanakan kegiatan PSN di lingkungan rumahnya secara rutin dan berkesinambungan (Notoatmodjo, 2007). Keberhasilan pelaksanaan PSN secara berkesinambungan sangat erat kaitannya dengan Promosi yang dilakukan oleh pihak terkait. Kegiatan penyuluhan kesehatan terhadap masyarakat perlu kerja sama dengan lintas sektor terkait, seperti 
lembaga swadaya masyarakat dan lembaga pemerintah daerah. Sasaran kegiatan penyuluhan adalah masyarakat yang berada jauh dari sarana pelayanan kesehatan. Penguatan sistem kesehatan dan membangun kerja sama lintas sektor merupkan hal penting dalam mengatasi masalah kesehatan dimasyarakat.

\section{METODE}

Penelitian ini bertujuan untuk menganalisa pengetahuan tentang DBD, Pemberantasan Sarang Nyamuk (PSN) 3M Plus dan pelaksanaan Pemberantasan Sarang Nyamuk (PSN) 3M Plus di masyarakat Desa Kamal, Kabupaten Bangkalan Propinsi Jawa Timur, Indonesia. Penelitian ini menggunakan metode kualitatif dengan pendekatan studi kasus. Populasi dalam penelitian ini adalah sebagian masyarakat yang tinggal di Kecamatan Kamal. Data dikumpulkan melalui wawancara mendalam dengan 13 ibu rumah tangga Desa Kamal, 1 tokoh masyarakat dan 1 petugas Puskesmas.

Pengumpulan data dilakukan selama periode Bulan April-Juni 2017. Respon narasumber cukup baik ketika pelaksanaan penelitian. Semua narasumber bersedia memberikan keterangan yang diminta pada saat wawancara mendalam.

\section{HASIL DAN PEMBAHASAN Karakteristik Informan}

Informan dalam penelitian ini terdiri dari dua kelompok. Kelompok pertama adalah reponden yang seluruhnya berjenis kelamin perempuan dengan status sebagai ibu rumah tangga. Mereka memiliki pendidikan SMP hingga Sarjana dan umumnya tidak bekerja. Sedangkan kelompok berikutnya adalah petugas puskesmas dan tokoh masyarakat dengan pendidikan sarjana.

\section{Pengetahuan Masyarakat tentang Pencegahan DBD}

Hasil analisa dari wawancara mendalam dengan informan, pengetahuan masyarakat tentang pencegahan DBD belum lengkap. Menurut Informan mencegah DBD dapat dilakukan dengan mengusir nyamuk menggunakan obat nyamuk bakar maupun semprot. Kemudian juga membersihkan kamar mandi, yang dilakukan sebulan sekali. Informan juga menjelaskan jika ada yang sakit DBD, maka masyarakat sekitar mengharapkan ada fogging. Baik dari Puskesmas maupun dari kantor desa. Seperti diungkapkan berikut ini:

“......Mencegahnya ya harus ngusir nyamuk. Pakai obat nyamuk ato semprotan nyamuk. Itu yang saya tahu. terus juga membersihkan kamar mandi. Cuma saya kadang sebulan sekali. itu yang bersihkan bukan saya. Orang-orang sini kalo ada yang sakit DBD itu biasa maunya ada semprotan. Dari Puskesmas atau dari desa. Jadi ya mencegahnya dengan semprotan...." (TI1 111 SBKO5, 43 th)

Semua ibu yang menjadi subjek penelitian ini memiliki pendapat yang sama bahwa pencegahan DBD itu dapat dilakukan dengan mengusir nyamuk menggunakan obat nyamuk bakar maupun semprot. Kemudian juga membersihkan kamar mandi, serta denga penyemprotan fogging.

Pengetahuan merupakan faktor yang mempengaruhi seseorang dalam berperilaku. Pengetahuan merupakan domain yang sangat penting dalam proses pembentukan perilaku. Perilaku yang didasari pengetahuan sifatnya akan lebih menetap dibandingkan dengan yang tidak disasari pengetahuan (Nototmodjo, 2010). Penelitian yang dilakukan Purnama, et al (2013), juga menunjukkan bahwa tingkat pengetahuan, sikap dan PSN mempunyai pengaruh terhadap infeksi DBD. Tidak jauh berbeda dengan penelitian yang dilakukan oleh Santos 
et all (2012) bahwa pengetahuan berhubungan dengan perilaku dalam pencegahan demam berdarah. Rendahnya pengetahuan masyarakat tentang penyebab DBD akan berpengaruh pada rendahnya pencegahan $\mathrm{DBD}$. Itrat, et al (2008) menjelaskan bahwa pengetahuan berhubungan dengan perilaku pencegahan DBD. Namun Nalonsack, et al (2009) menjelaskan bahwa pengetahuan yang baik belum tentu memiliki tindakan yang baik pula.

\section{Pengetahuan Masyarakat tentang Pemberantasan Sarang Nyamuk (PSN) 3M Plus}

Hasil lain dari penelitian ini juga diketahui bahwa masyarakat belum mengenal secara mendetail dalam hal pelaksanaan PSN 3M Plus. Hal ini disebabkan kurangnya pengetahuan tentang pelaksanaan PSN 3M Plus. Kurangnya pengetahuan masyarakat Desa Kamal tentang PSN 3M Plus tidak lepas dari peran pihak terkait. Masyarakat belum pernah mendapatkan informasi secara benar tentang PSN 3M Plus. Seperti terungkap dalam wawancara berikut:

“......Penyuluhan ? Selama saya tinggal disini belum ada penyuluhan. Penyuluhan DBD atau PSN. Selama disini belum pernah sih ikut penyuluhan. Lha mang gak ada mbak. Seharusnya sih penyuluhan itu perlu. Ya biar orang tau apa itu DBD dan PSN.......". (MAR, 43 tahun)

Namun informan dari Puskesmas memberikan keterangan yang sedikit bertentangan dengan masyarakat. Informan menjelaskan bahwa penyuluhan biasa dilakukan disekolah atau bersamaan dengan kegiatan lain, misalnya Posyandu. Sehingga ibu yang tidak memiliki balita dan tidak pergi ke Posyandu tidak mendapatkan informasi yang telah diberikan oleh petugas.

Pemberantasan Sarang Nyamuk (PSN) merupakan program telah diintensifkan sejak tahun 1992. Pada tahun 2000 dikembangkan menjadi 3M Plus yaitu dengan cara menggunakan larvasida, memelihara ikan dan mencegah gigitan nyamuk. Program ini tidak berdampak signifikan, hal ini bisa terlihat semakin tingginya kasus DBD di Indonesia. PSN 3M Plus sebagai salah satu metode pengendalian DBD ternyata kurang familiar bagi masyarakat. Umumnya informan tidak mengetahui istilah PSN.

Rendahnya pelaksanaan PSN 3M Plus ini berkaitan dengan rendahnya pengetahuan masyarakat tentang PSN 3M Plus. Berdasarkan penelitian yang dilakukan Monintja (2015) ada hubungan antara karakteristik, pengetahuan dan sikap dengan tindakan pencegahan DBD, hal ini senada dengan penelitian yang dilakukan Nuryanti (2013) di Kabupaten Blora Jawa Tengah, menunjukkan bahwa ada hubungan yang signifikan antara tingkat pengetahuan dengan perilaku PSN. Demikian juga dengan penelitian yang dilakukan Itrat, et al (2008) di Pakistan menunjukkan bahwa pengetahuan berhubungan dengan perilaku pencegahan DHF.

\section{Pelaksaanaan Pemberantasan Sarang Nyamuk (PSN) 3M Plus}

Program pemerintah dalam menanggulangi DBD adalah Pemberantasan Sarang Nyamuk (PSN), pengasapan (fogging), dan larvasida. Di Kamal, masyarakat lebih mengenal fogging dan larvasida daripada PSN 3M Plus. Berdasarkan pengamatan tidak semua masyarakat melakukan kegiatan PSN 3M Plus secara lengkap. Tindakan PSN 3M Plus yang kurang lengkap berkaitan dengan pengetahuan dan pemahaman mereka yang kurang. Mereka tidak menutup tempat penampungan air karena belum mengetahui. Sedangkan tidak melakukan penguburan karena langsung membuang ke laut. Hal ini terungkap pada petikan wawancara berikut: 
“....Memang sebelum kaleng-kaleng itu dibuang kalo pas hujan ada air menggenang. Tapi setelah saya buang ya hilang. Kalo buang sampah memang ke laut kok. Orang sini rata-rata kalo buang sampah ya ke laut mbak. Mau kemana lagi, gak ada yang ngangkut. Mau dibakar dimana, rumah gak ada halamanannya....". (JUH, 34 tahun)

Menurut informan dari Puskesmas, masyarakat bukan hanya melakukan kegiatan PSN 3M Plus yang tidak lengkap. Masyarakat kurang memperhatikan lingkungan sekitar rumah. Misalnya selokan yang tergenang air, tempat makan dan minum hewan ternak yang tidak dibersihkan. Rendahnya pelaksanaan PSN berhubungan dengan tingginya angka kejadian DBD. Hasil penelitian Jaya dkk (2013), menunjukkan bahwa menutup dan menguras TPA berhubungan dengan keberadaan larva Aedes Aegyptyi. Hasil penelitian lain oleh Purnama, et al (2013), menemukan bahwa pengetahuan, sikap dan perilaku PSN yang rendah dapat meningkatkan terjadinya infeksi dengue. Hal ini senada dengan Hasan dan Ayubi (2007) menunjukkan bahwa ada hubungan kebiasaan melakukan PSN dengan kejadian DBD, individu yang tidak melakukan PSN berisiko 5,85 kali terkena DBD dibandingkan dengan individu yang melakukan PSN.

\section{Upaya Peningkatan Pelaksanaan PSN 3M Plus yang Berkesinambungan}

DBD merupakan masalah kesehataan masyarakat yang sampai saat ini sulit diberantas. Banyak faktor yang mendasari sulitnya pemberantasan DBD, dan salah satu faktor adalah pengetahuan. Pengetahuan yang positif juga diiringi sikap dan perilaku positif. Hal ini karena dipengaruhi oleh faktor lain, seperti motivasi, niat, kehendak dan pengalaman (Notoatmodjo, 2007). Perilaku ditentukan oleh pengetahuan, sikap, kepercayaan, tradisi. Jika seseorang memiliki pengetahuan tentang suatu objek maka diharapkan orang tersebut memiliki sikap dan perilaku positif juga. Pengetahuan merupakan aspek yang penting untuk mendasari perubahan perilaku. Perubahan perilaku tidak terjadi kecuali individu mendorong melakukan tindakan tertentu atas dasar pengetahuan yang dimilikinya. Merujuk pada Sayavong et al. (2015), bahwa pengetahuan yang baik, akan menunjukkan perilaku yang baik. Namun tidak selamanya pengetahuan yang baik tidak selalu mengarah pada praktik yang baik pula (Ho et al., 2013).

DBD dan PSN 3M Plus adalah informasi yang dibutuhkan oleh masyarakat Desa Kamal. Sehingga akses informasi tentang keduanya harus diperluas. Namun studi menunjukkan bahwa informasi hanya diperoleh melalui televisi dan media lainnya. Informan dari Puskesmas juga mengatakan bahwa penyuluhan hanya diberikan di Sekolah dan Posyandu. Sehingga masyarakat yang anaknya tidak sekolah atau yang tidak memiliki balita tidak memperoleh informasi tentang DBD dan PSN. Untuk itu perlu upaya peningkatan pengetahuan masyarakat tentang pentingnya pelaksanaan PSN 3M Plus melalui promosi kesehatan yaitu dengan penyuluhan.

Hasil studi menunjukan bahwa penyuluhan diperlukan untuk meningkatkan pengetahuan dan mengubahnya dalam perilaku (Ibrahim et al., 2009). Adanya rangsangan dari luar (penyuluhan dari petugas kesehatan) akan mempengaruhi perubahan perilaku seseorang. Penyuluhan yang diberikan oleh petugas kesehatan tentang DBD dan PSN 3M Plus yang dibantu oleh kader kesehatan serta tokoh masyarakat akan mempengaruhi terjadinya perubahan perilaku masyarakat dalam melaksanakan PSN 3M plus. Penyuluhan dari petugas kesehatan merupakan faktor penguat atau melemahkan terjadinya perubahan perilaku. Penyuluhan yang diberikan oleh petugas kesehatan kepada 
masyarakat akan mempengaruhi pengetahuan baik dan sikap positif yang akhirnya akan terjadi suatu perilaku PSN 3M plus. Hasil penelitian ini sejalan dengan penelitian yang dilakukan oleh Nuryanti (2013) menyebutkan bahwa terdapat hubungan antara peran petugas kesehatan dengan praktik PSN DBD oleh masyarakat.

Kegiatan penyuluhan kesehatan terhadap masyarakat perlu kerja sama dengan lintas sektor terkait, seperti lembaga swadaya masyarakat dan lembaga pemerintah daerah. Sasaran kegiatan penyuluhan adalah masyarakat yang berada jauh dari sarana pelayanan kesehatan. Penguatan sistem kesehatan dan membangun kerja sama lintas sektor merupakan hal penting dalam mengatasi masalah kesehatan di masyarakat.

Kegiatan penyuluhan harus dilaksanakan dengan menjangkau segenap masyarakat, sampai dengan terbentuk dan terpelihara partisipasi masyarakat. Dengan demikian, aktivitas pengendalian vektor DBD harus berbasis pastisipasi masyarakat. Partisipasi masyarakat adalah ikut sertanya seluruh anggota masyarakat dalam memecahkan permasalahan-permasalahan masyarakat tersebut. Partisipasi masyarakat di bidang kesehatan berarti keikutsertaan seluruh anggota masyarakat dalam memecahkan masalah kesehatan mereka sendiri (Notoatmodjo, 2005). Partisipasi masyarakat melalui kegiatan penggerakan PSN pada dasarnya adalah upaya memotivasi masyarakat untuk menjaga rumah dan lingkungannya agar terbebas dari jentik dan nyamuk penyebab DBD kegiatan ini perlu dilakukan secara berkesinambungan dengan melibatkan unsur-unsur masyarakat.

\section{PENUTUP}

Dari hasil penelitian ditemukan bahwa pengetahuan masyarakat tentang DBD dan PSN 3M Plus belum lengkap. Masyarakat lebih mengenal fogging dan larvasida untuk menanggulangi DBD daripada program PSN 3M Plus. Rendahnya pelaksanaan PSN 3M Plus dan minimnya informasi mengenai DBD dan PSN 3M Plus. Sebagai rekomendasi, sebaiknya pihak terkait segera mengambil langkah strategis dan tekhnis dalam pelaksanaan PSN 3M Plus sebagai pendekatan utama dalam pengendalian DBD. Memfasilitasi kemitraan antara masyarakat dan pemerintah serta mengupayakan partisipasi masyarakat dalam menanggulangi DBD melalui kegiatan penggerakan PSN. Memperluas akses informasi tentang DBD dan PSN 3M Plus, bukan hanya di sekolah namun juga mencakup seluruh lapisan masyarakat.

\section{DAFTAR PUSTAKA}

Dinkes Provinsi Jawa Timur. 2016. Profil Kesehatan Propinsi Jawa Timur. Surabaya: Dinkes Provinsi Jawa Timur.

2015. Profil Kesehatan Propinsi Jawa Timur. Surabaya: Dinkes Provinsi Jawa Timur.

2014. Profil Kesehatan Propinsi Jawa Timur. Surabaya: Dinkes Provinsi Jawa Timur.

Dinkes Kabupaten Bangkalan. 2016. Profil Kesehatan Kabupaten Bangkalan. Bangkalan: Dinkes Kabupaten Bangkalan.

Bangkalan: Dinkes Kabupaten Bangkalan. 2015. Profil Kesehatan Kabupaten Bangkalan. 2014. Profil Kesehatan Kabupaten Bangkalan.

Bangkalan: Dinkes Kabupaten Bangkalan.

Hasan A \& Ayubi D. 2007. Hubungan Perilaku PSN dengan Kejadian DBD di Kota Bandar Lampung. Jurnal Kesehatan Masyarakat Nasional. 2(2): 86 90.

Ho TS, Huang MC, Wang SM, Hsu HC. 2013. Knowledge, Attitude and Practice 
Of Dengue Disease Among Health Care Professionals In Southern Taiwan. Journal Of The Formosan Medical Association. 112: 18-23.

Ibrahim NK, Al-Bar A, Kordey MFA. 2009. Knowledge, Attitude Practices Relating To Dengue Fever Among Females in Jeddah High Schools. Journal of Infection and Publich Health. 2: 30-40.

Itrat A, Khan A, Javaid S, Kamal M, Khan H, Javed S, Kaliaa S, Khan AH, Sethi, MI, Jehan I. 2006. Knowledge, Awareness and Practices Regarding Dengue Fever among the Adult Population of Dengue Hit Cosmopolitan. Plosone. 3 (7): $1-3$.

Jaya MD, Ibrahim E, Anwar. 2013. Hubungan PSN DBD Dengan Keberadaan Larva Aedes Aegyptyi Di Wilayah Endemis DBD Kelurahan Kasi-Kasi Kota Makasar. Naskah Publikasi. Makassar: Universitas Hasanuddin. URL: http: / / repository.unhas.ac.id/

Kementrian Kesehatan RI. 2016. Profil Kesehatan Indonesia 2016. Jakarta: Kementrian Kesehatan RI.

Kementrian Kesehatan RI.

2015. Profil Kesehatan Indonesia 2015. Jakarta:

. 2014. Profil Kesehatan Indonesia 2014. Jakarta:

Kementrian Kesehatan RI.

2010. Buletin Jendela Epidemiologi. Demam Berdarah Dengue. Jakarta: Kementrian Kesehatan RI.

Monintja TCN. 2015. Hubungan antara Karakteristik, Pengetahuan dan Sikap Dengan Tindakan PSN DBD Masyarakat Kelurahan Malalayang, Manado. Jurnal Ilmu Kesehatan Masyarakat Universitas Samratulangi. 5(2): 503 519.

Nalongsack S, Yoshida Y, Morita S, Sosouphani K dan Sakamoto J. 2009. Knowledge, Attitude and Practice Regarding Dengue Among People In Pakse Laos. Nagoya Journal Medicine Sciene. 7(1): 29 - 37.

Notoatmodjo S. 2010. Imu Perilaku Kesehatan. Rineka Cipta. Jakarta.

Jakarta. 2007. Kesehatan Masyarakat Ilmu dan Seni. Rineka Cipta. 2005. Promosi Kesehatan: Teori dan Aplikasi. Rineka Cipta. Jakarta.

Nuryanti E. 2013. Perilaku Pemberantasan Sarang Nyamuk Di Masyarakat.. Jurnal Kesehatan Masyarakat. 9(1): 15 - 23.

Purnama SG, Satoto TB, Prabandari Y. 2013. Pengetahuan, Sikap dan Perilaku PSN Terhadap Infeksi Dengue Di Kecamatan Denpasar Selatan, Kota Denpasar, Bali. Arc. Com. Health. 2(1): $20-27$.

Santos SL, Henao GP, Silva MB, Augusta LG. 2012. Dengue In Brazil And Colombia: A Study Of Knowledge, Attitudes, And Practices. Revista da Sociade Brasileira de Medicine Tropical. 47(6): 783 - 787.

Sayavong C, Chompikul J, Wongsawass SRC. 2015. Knowledge, Attitudes And Prenventive Behaviors Related To Dengue Vector Breeding Control Measures Among Adults In CommunitiesOf Vientiane, Capital Of The Lao PDR. Journal Of Infection And Publich Healt. 8: 466-473. 